\title{
Correction to: Mesenchymal stem cells in the treatment of severe COVID-19
}

Santosh Kesari ${ }^{1 *}$, Gregory C. Kasper ${ }^{2 *}$, Lev Verkh ${ }^{3}$, Terese C. Hammond ${ }^{4}$, Marla L. Matal2 ${ }^{2}$, Jay W. Hammerling ${ }^{2}$, Nikolai Tankovich ${ }^{3}$, Adrianus P. Lim², Kevin H. Zhao ${ }^{2}$, Tiffany Juarez' ${ }^{1}$, Roberta E. Redfern², Jaya M. Gill' Natsuko Nomura', Audrey Hiemer' ${ }^{1}$, Annie Heng ${ }^{1}$ and Jessica Shoemaker ${ }^{2}$

\section{Background}

Correction to: Transl Med Commun 6, 16 (2021)

https://doi.org/10.1186/s41231-021-00095-0

Following publication of the original article [1], the authors reported an error in the list of affiliations and requested to remove affiliation 2 "University of California San Diego Health System, Translational Neurosciences and Neurotherapeutics, Santa Monica, CA 90404, USA."

The original article [1] has been updated.

\section{Author details}

'Pacific Neuroscience Institute and Providence Saint John's Health Center, Santa Monica, USA. ${ }^{2}$ ProMedica Toledo Hospital, 2142 North Cove Blvd, Toledo, OH 43606, USA. ${ }^{3}$ Stemedica Cell Technologies, Inc., San Diego, USA. ${ }^{4}$ Providence Saint John's Health Center, Santa Monica, USA. ${ }^{5}$ Pacific Neuroscience Institute, Santa Monica, USA.

Published online: 23 August 2021

\section{Reference}

1. Kesari $S$, Kasper GC, Verkh $L$, et al. Mesenchymal stem cells in the treatment of severe COVID-19. TransI Med Commun. 2021;6:16. https://doi. org/10.1186/s41231-021-00095-0.

\section{Publisher's Note}

Springer Nature remains neutral with regard to jurisdictional claims in published maps and institutional affiliations.

The original article can be found online at https://doi.org/10.1186/s41231-

021-00095-0.

*Correspondence: santoshkesari@gmail.com; Gregory.

KasperMD@promedica.org

${ }^{1}$ Pacific Neuroscience Institute and Providence Saint John's Health

Center, Santa Monica, USA

2 ProMedica Toledo Hospital, 2142 North Cove Blvd, Toledo, OH 43606,

USA

Full list of author information is available at the end of the article

(c) The Author(s) 2021. Open Access This article is licensed under a Creative Commons Attribution 4.0 International License, which permits use, sharing, adaptation, distribution and reproduction in any medium or format, as long as you give appropriate credit to the original author(s) and the source, provide a link to the Creative Commons licence, and indicate if changes were made. The images or other third party material in this article are included in the article's Creative Commons licence, unless indicated otherwise in a credit line to the material. If material is not included in the article's Creative Commons licence and your intended use is not permitted by statutory regulation or exceeds the permitted use, you will need to obtain permission directly from the copyright holder. To view a copy of this licence, visit http://creativecommons.org/licenses/by/4.0/. 